\title{
Karl Ove Knausgaard and the Transformation of Honor Culture in Late Modern Welfare States
}

\author{
Per Thomas Andersen \\ University of Oslo \\ p.t.andersen@iln.uio.no
}

\begin{abstract}
The six-volume novel, My Struggle (2009-2011), by the Norwegian author Karl Ove Knausgaard has been received with great enthusiasm in many parts of the world. This article analyzes the novel and its reception from the historical perspective of traditional honor culture coming to an end in some late modern welfare states. Focusing on shame and dishonor, the article situates the autobiographical project in a contemporary moment granting the author the freedom to write himself out of traditional honor groups and into new "floating" honor groups, like that of the celebrities of our time.
\end{abstract}

\section{Keywords}

Knausgaard - autobiographical novel - Scandinavian literature - theory of honor - late modern welfare states

An unmistakable characteristic of influential writers is that they create their own reader, a new type of reader that did not exist before. At least this is what happened in Karl Ove Knausgaard's home country, Norway, and the neighboring Scandinavian countries, when he published his six-volume novel, $M y$ Struggle (2009-2011). All of a sudden hundreds of thousands of Scandinavians found themselves with an insatiable drive for reading infinitely long novels with no plot, no heroes, no anti-heroes, no clear message, just stories overburdened with details about trivial everyday events and everyday thoughts. In a relatively short period of time his books sold more than half a million copies in Norway, a country of about five million inhabitants. Reviews were almost invariably strongly enthusiastic, and Knausgaard received several liter- 
ary awards. Initially one would expect this to be a rather local phenomenon, as readers could be triggered by a piquant aspect of the project; one could also recognize real-life, prominent figures in the novels. These were not ordinary novels, but autobiographical texts, telling the story of Karl Ove Knausgaard's own life, his family relations, friendships and encounters with people in small, recognizable towns, communities and literary environments. But soon translations started to appear, and it turned out that the potentially scandalous part of the project was not the most important one. By far the most enthusiastic response came from neighboring Denmark, where literary critics continue to praise Knausgaard as a new deity on the literary pantheon. There is no reasonable restraint in the excitement. The literary critic Marie Tetzlaf prophetically states that "Knausgaard's masterpieces will become as influential as Goethe." Chances are relatively high that Tetzlaf will not live the necessary 180 years to see if she was right. She is, however, representative of the unrestrained euphoria Knausgaard has been received with in Denmark.

Most critics in the other Scandinavian countries have been highly excited as well, but both in Norway and Sweden there have been some critical voices. In Sweden, Knausgaard has been met with resistance from feminist and gender political positions, and in Norway his family has reacted rather violently, calling his novels Judas-literature, due to the exposure of his own family. Reactions started to come from outside the Scandinavian countries as well, mostly very enthusiastic reviews from countries like the Netherlands, Italy and Spain, and after a while even the English-speaking world, with the Us and the UK joining the chorus of voices. In 2012, James Wood wrote in The New Yorker that "even when I was bored I was interested." So it turns out that Knausgaard had managed to create a new type of reader even outside Scandinavia. The bored enthusiast that cannot get enough of Knausgaard's 3500 pages of triviality must be a rather sensational reader, even in the us.

Along with the outstanding reviews, Knausgaard received a number of literary awards as well. It started with the local Norwegian awards, but then suddenly Knausgaard had to go to New York to receive The Wall Street Journal's Innovator Reward 2015 in the company of celebrities like Robert de Niro, Angelina Jolie, Brad Pitt and Zadie Smith. What professional critics as well as ordinary readers tend to emphasize when they describe their reading experience is that they recognize their own lives in his depictions, and that his focus on trivial and banal aspects of life increases the value of the reader's own everyday life. As John Powers puts it on National Public Radio (N PR):

As I was reading, every single subject that came up in $m y$ daily livingparents, politics, education, Italian food, trees, even David Byrne- 
reminded me of something in Knausgaard. His work makes you realize that each and every one of our lives contains rich enough material for a long, daunting book called My Struggle.

However, there are obviously cultural limitations to the possibility of identifying with a young man's rather privileged life and individualized personal self-perception in contemporary Norway. If My Struggle is world literature, it is probably not because the depictions of life are universal. The work has been translated into many languages and is widely recognized, but what makes it relevant in a world perspective is the implicit depiction of an "after honor" culture, made highly relevant because of the cultural encounters today between intact and impaired honor cultures in some European welfare states. This will be the perspective in the following.

\section{A Literary Long Distance Runner}

Karl Ove Knausgaard (born 1968) made his literary debut in 1998 with the voluminous novel Out of the World. From the outset of his career he was met with considerable attention and received several literary awards. Knausgaard is a literary long distance runner. His first novel comprised 700 pages; the next one, A Time for Everything (2004), more than $55^{\circ}$ pages; and My Struggle is a 3500-page project. Knausgaard's prose is characterized by its expanding technique, fortspinnung is his compositional basic principle. He cares a lot about details and loves additive associations. For the most part, Knausgaard writes a calm, floating normal prose, sometimes with a slight archaic touch. Narrative parts are often interrupted by essayistic elements. Surprises are more often found in his leaps of thought and digressions than in his style. There are, however, poetic qualities in his descriptive sections, and occasionally one will find metaphorical subtleties: "a path that turns hither and thither seems like it is laid out by a puppy-dog," Knausgaard writes in A Time for Everything.

My Struggle is an autobiographical text that is labeled a novel on the front cover. Facts and fictionalizing literary techniques are interwoven. This is probably why most of the academic interest in Scandinavian countries has focused on the question of genre. There is a cluster of ambiguities involved in the project. The position of the reader is indeterminable as it waivers between a traditional "autobiographical pact" and a fiction-contract with the reader. The sender-position is equally ambiguous as the "I" in the text flickers between a remembering and a remembered subject. The third ambiguity could be envisaged between the writer of the text and the artist who decided to publish it. 
The private person, writing at his desk had a therapeutic project, Knausgaard has publicly stated (Zennström 39-49). The professional author who decided to publish the novels clearly must have had an artistic ambition in addition to the private business. How Knausgaard succeeded with his private project is hard to decide. In several interviews he has been talking about it with strong regret. However, great success with his artistic ambitions must have surpassed all his expectations.

The title of the project, My Struggle, is Min kamp in Norwegian, identical with the title of Adolf Hitler's book Mein Kampf. In volume six there is a lengthy essay on Hitler, but the connection between the struggles of the two men involved is not obvious, and in the first five volumes the title only makes one wonder why this rather provocative intertextual connection is mobilized. In the initial Norwegian edition of the novels they share the common title Min kamp $I-V I$. In some of the translations each book has got its own title indicating a basic theme, like A Death in the Family, A Man in Love, Boyhood Island and so on. All volumes follow the same compositional principles: a rather freefloating text with simple shifts between narration, reflection, description and essayistic elements. The dominant principle is chronological narration. But the timeline is interrupted rather frequently by anachronies, mostly analepses or flash backs in the narrator's mind; there are achronies as well. In the first part of the first volume, one will notice that several different types of faces show up in the text serving as leitmotifs and adding a kind of compositional strength to the text, connecting the narrative and essayistic elements. However, the motif subsequently disappears from the text which then runs rather freely following associations of the narrator's mind. It is probably this portrayal of an individual mind that has fascinated such a huge number of readers, though not basically in an abstract sense. Most important are the topics, the feelings and reflections that occupy the mind, and among these are the complex topics of honor, shame, freedom and belonging.

\section{From Honor Culture to Late Modern Welfare State}

Scandinavian societies have evolved from rather extreme honor cultures to late modern cultures in which equality is the governing norm, perhaps more so than in any other region in the world. These cultural roots are clearly depicted in the old sagas from the Viking age. Among the most famous ones we find the saga of Egil Skallagrimsson in which we are told about the upbringing of a hero, Egil. As a seven-year-old child, he was once playing ballgames together with the ten-year-old Grim. Unfortunately, Egil lost the competition. This made him 
so mad that he hit Grim with a bat; but Grim was the bigger of the two and lifted Egil up and threw him on the ground. Egil then went to the adults in his guild and picked up an axe. According to the saga "Egil then rushed towards Grim, and hewed the axe into his head so that it stood firmly in his skull." The consequence was not that Egil was taken away from his parents and put into child-care by the child protection agency, but the killing led to a conflict in which seven men lost their lives. Egil's father, the old Skallagrim, was not too happy with the incident. But his mother was rather proud, and said that Egil was a true Viking, and that he should have his own warship as soon as he was old enough. Later in Egil's life, there were more and more of the same kind of events. Excessive wrath, violent temperaments, free floating anger, and over-sensitivity to loss of honor were the admirable traits of the celebrities of the time. In social life, what initiated all serious events were a strong sense of honor and readiness for violence. The events followed a repeated script: sense of honor, infringement of honor, anger, violence/revenge, retribution, and reretribution (i.e. the spiraling of violence). In Old Norse culture, honor was more important than life itself. The ultimate life value was one's posthumous reputation, and that could be worth dying for. It is important to emphasize that honor was the principle by which society functioned. There was no executive power, no police force; every citizen had to protect his or her own reputation, rights and property, and to do so every person had to rely on his or her own family and guild.

Later in history, Christianity acquired the notion of honor. The honor of the guild was replaced by the honor of God. The relation between external and internal honor has changed throughout history. Two of the most wellknown representations of European honor culture, the culture of chivalry and the Victorian so-called "Christian gentleman-culture" appear to be cases in which both external and internal honor played an important part. In general, one could say that honor culture continued, but the honor belonged to God in Heaven. And yet quite an amount of honor dripped down through the hierarchy of the church as well. Popes and priests managed to make their fortunes by other methods than the Vikings, but their methods seem to have been as effective as the Viking raids.

As to the historical development, it is important to note that even though there was a substantial Christian influence on European honor culture, a phenomenon like dueling in which men solved infringements of honor risking their lives man against man, continued throughout most of the nineteenth century, in some cases even into the twentieth century. Concurrent with Christianity's idea of forgiveness and humility, the more primitive duel culture still existed throughout the centuries. A historic change began to develop in the age 
of modernity. The anti-hero appeared in literature, especially in the tradition from Rabelais and Cervantes, and we can already see a nascent undermining of European honor culture. At the beginning of the modern breakthrough this development was enforced. This is noticeable in several of Ibsen's male characters; in fact, it is an important aspect of Ibsen's anti-heroism. In A Doll's House, for instance, Helmer utters to his wife Nora: "I would gladly toil day and night for you, Nora, enduring all manner of sorrow and distress. But nobody sacrifices his honour for the one he loves." Nora replies curtly: "Hundreds and thousands of women have" (Ibsen 284). There is no doubt, that at the end of the play Helmer is left with no honor whatsoever.

European honor culture went through an intense period of decline and fall during the first half of the twentieth century. According to James Bowman in Honor: A History, this is due to the two World Wars. Modern warfare more or less put an end to honor culture at least in the northern part of Europe, and in this respect the Second World War can be regarded as an extension of the First. The undermining of any conception of honorable warfare was due to the enormous number of casualties, but equally important was the industrialization and anonymization of the acts of killing. Questions of life and death were totally random because of new technologies like the machine gun, the mortar and the gas attacks. "If a machine gun could wipe out a whole battalion of men in three minutes," asks John Ellis in The Social History of the Machine Gun, "where was the relevance of the old concept of heroism, glory and fair play between gentlemen?" (142). During the Second World War, area bombing and the annihilation of large cities made civilians targets of largescale terror and murder. In Honor: A History, Bowman has a chapter entitled "Area Bombing and the Demise of Honor Culture" ( $16 \mathrm{gff}$.). The analysis of a number of cases contributes to the conclusion that this kind of warfare made it impossible for Europe to ever claim cultural honor again. By these acts, European/North American Civilization has made itself dishonorable in a historical perspective.

After the Second World War, the Scandinavian welfare states developed in which traditional honor culture was replaced by an equality-focused culture in which social and political equal rights dominate the hierarchy of values.

\section{External and Internal Honor}

In Upheavals of Thought, Martha Nussbaum claims: "A culture that values honor highly, and attaches a strong negative value to the slighting of honor, will have many occasions for anger that an equality focused culture ... will not have" 
(157). Julian Pitt-Rivers, one of the pioneers of modern honor research, highlights three facets in his definition of honor: "a sentiment, a manifestation of this sentiment in conduct, and the evaluation of this conduct by others" (503). However, it is more common within the field of research to rely on only two aspects, external and internal honor. External honor pertains to one's personal reputation, prestige and social value in the opinion of others. Internal honor is more or less synonymous with personal integrity or character, individual quality or honorableness. This differentiation is what Frank Henderson Stewart calls "the bipartite theory" of honor (19). Honor, anger and shame are hardly universal affects. They are, as Nussbaum claims, connected to social norms. Honor is connected to specific honor groups, to which individuals belong or with which they identify. Different honor groups have different honor codes, and the groups may be large and extensive (like cultural groups or nations) or small and limited (like professional groups). Also subgroups within larger societies exist in which deviant honor codes are normative (such as criminal groups). With its Greek and Roman heritage, European culture is an old honor culture. "Homeric man's highest good is ... enjoyment of time, public esteem," claims E.R. Dodds (17-18). The Old Norse culture was an even more extreme honor culture. Today, however, European honor culture is impaired. The reasons might be of several kinds. Stewart emphasizes the individualization of western cultural values, what he calls the "integrity position" (51). Beyond doubt the historical reasons emphasized by Bowman play an important part as well. The relevance of this topic is that the cultural clash between intact honor cultures and "after honor" cultures represents one of the most serious conflicts in contemporary societies.

\section{Shame and Dishonor in My Struggle}

I will argue that My struggle represents late modernity especially when it comes to the decline of an honor culture. While honor historically was crucial for the way society worked, how it disciplined its citizens and how it regulated the relations between individuals and groups, it no longer-in late modern times-plays an important part in political governing and cultural education of society in general. In fact, there are quite a number of examples indicating that a kind of anti-honor culture has evolved, especially in the cultural field. Performing notoriously embarrassing behavior has become a winner concept in comedy, and it is more than possible, maybe even recommendable, to build fame and celebrity status on ways of behavior that would traditionally be regarded as devastating for personal honor. It is sufficient to mention 
Rowan Atkinson's success with Mr. Bean and Sasha Baron Cohen's successful film Borat. Openness about traditionally shameful or dishonorable phenomena is however not restricted to comedy. The former Norwegian Prime Minister Kjell Magne Bondevik scored extra bipartisan points by talking openly about his psychological torments and his treatment. This example indicates an important aspect of the potentially shameful or dishonorable in late modernity, which works as a proof of honesty and authenticity - virtues that late modern people appreciate highly. The courage to be "open" about private matters is today regarded as braver than courageous violence in war. Formerly shameful phenomena do not necessarily lead to shame any more. On the contrary, in some cases it gives you credit. Openness about former shame topics might be one of several gains from the decline of an honor culture. It has become possible to talk about personal psychological torments, bullying, sexual orientation, and so on, and this might have produced more tolerance in society at large. Knausgaard is often characterized as "brutally honest" on private topics (Jordan).

However, revealing one's private life automatically leads to revealing that of others. Brutality has become a highly rated virtue when it comes to openness about one's own private life. It might be easy to agree that everyone has the ownership of his or her own life and life story. But most of us would be able to recognize that brutality is more problematic when it comes to openness about the life of others, especially if one insists on being "open" to the public about highly personal information. Those who are involved might be defenseless, as for example children are, or they may contest the truth-value of the information.

No cultural phenomenon actualizes questions like these more clearly than Karl Ove Knausgaard's work My Struggle. Knausgaard has gained greater and faster prestige than any other participant in Norwegian public life in recent years, and it is all based on revealing intimate events that traditionally would have been regarded as irrelevant to public life. Some events are even quite shameful or dishonorable, according to traditional honor codes.

In his book, Honor: A Phenomenology, Robert R. Oprisco makes the point that it is relevant to distinguish between shame and dishonor in connection with transgressions within an honor culture: "Shame is a fact of life. The society will have expectations for each member based upon their identities and their past actions" (73). He underlines that "prestige is gained through excelling. Shame is avoided by not failing" (71). The anthropologist Unn Wikan holds the opinion that in honor cultures it is more common to be concerned about avoiding shame than gaining honor. In the late modern version we find in Knausgaard, this fear of shame seems to be strongly reduced. This is explicitly expressed 
in My Struggle II: Jeg driter i meg selv på den måten ("I don't give a shit about myself"; Min kamp 2, 162; My Struggle Book 2, 168). He does not care about himself in connection with openness about embarrassing or dishonorable events, he claims. An obvious example is the detailed depiction of premature ejaculation in connection with his sexual encounters with women. His own adultery does not bother him either. The same holds true in cases where he is the victim of others' adultery. In accordance with statistical knowledge about late modern changes in intimacy, such events are registered as trivial rather than dishonorable. Drunkenness, failure, stupidity and hooliganism during the time he lived in Bergen are depicted in the same way. Admittedly he seems sensitive towards his own failure, but not very embarrassed or shameful. He has no need to hide away. On the contrary, he seems indifferent towards the "expectations" which "society" might have, and the kind of prestige one could gain "through excelling." My struggle depicts both a brutally honest protagonist and a sort of a shameless person.

At this point it is relevant to add that it is not that Knausgaard is unable to feel shame. In fact, he often feels small in the company of others. The most dramatic shame-episode unfolds at a seminar together with other authors. Knausgaard is rejected by a woman (in fact the woman who later becomes his wife). This upsets him so much that he uses a piece of broken glass to cut up his own face. The day after, and in the company of his fellow seminar participants, there is no doubt that he feels intensely shameful. But he is not ashamed of telling about his shamefulness in detail in the novel. He writes about it in detail and thus exposes his shamefulness to others instead of hiding it away. Outside his work, Knausgaard even seems to regard shame as a basic mood of his life, and his publisher tells him that he is at his best as an author every time he writes about something shameful (Barron). Knausgaard claims that he has a kind of shame meter. Shame is not something alien to him. What is shameless is that he enjoys telling about it, that he "doesn't give a shit about himself in that way" (My Struggle Book 2, 168).

Unlike shame, dishonor is, according to Oprisco, directed against an honor group, not against oneself. "Dishonor differs from shame ... because it actually engages the values of a group to dismiss it," Oprisco writes (69). The most controversial aspect connected to My Struggle is probably its "brutal honesty" regarding individuals representing honor groups to which the author himself would traditionally belong, that is his family and his guild. Knausgaard's family members have heavily protested against his project. In October 2009, they published an article in Klassekampen in which they stated: "This is confession literature and non-fiction. Judas literature. This is a book full of insinuations, lies, erroneous characterizations of individuals and revealing acts that are obviously 
unlawful." This conflict between Knausgaard and his family is the most obvious example of how far away from traditional honor culture late modern values have moved. Knausgaard not only dishonors his father's posthumous reputation and his guild's social prestige, but even reveals intimate information about former girlfriends, his current wife and children and a number of friends. He violates traditional social norms regarding honorable behavior towards prime honor groups.

Knausgaard's project represents the decline and fall of the traditional honor culture through the protagonist's seeming indifference towards personal shame, and through his disloyalty towards traditional honor groups. Knausgaard himself stresses his need to be alone. He wants to be free. But he is not alone at all. On the one hand, he writes himself out of and free from traditional honor groups; but, on the other hand, he writes himself into new honor groups, late modern honor groups to which he wants to belong: that is, honor groups which are not based on family and friendship but fame. The prime honor groups in late modern times are based on prestige, excellence, fame, and celebrity status.

Prestige is the conception of honor that positively affects an individual's hierarchical social value in a group. Prestige is the process whereby external groups grant honor to a member for achieving or displaying excellence in deeds and attributes considered good by said group.

OPRISCO 63

Oprisco claims that his definition of prestige resembles Stewart's notion of "vertical honor," as "the right to special respect enjoyed by those who are superior" (Stewart 59). He lists a number of virtues that could evoke such special respect, but he ends his list by mentioning "or anything else." Oprisco writes: "A person can get honored for anything as long as it is of value to and considered virtuous by the honor-bestowing sovereign" (63). It should thus surprise no one that one can achieve "vertical honor" based on phenomena that outside a specific honor group (e.g. writers) would traditionally be regarded as dishonorable. In his book, Honor for Us: A Philosophical Analysis, Interpretation and Defense, W.L. Sessions distinguishes between "conferred honor," "recognition honor" and "positional honor." In Knausgaard's case, it is all about "recognition honor," which according to Sessions is most highly rated. There is however no doubt that this leads directly to "positional honor." Knausgaard's My struggle made him the most famous Norwegian writer domestically and internationally within a very short span of time. By this I do not mean to insinuate that the scandalous aspects of the work are the only reason for his achieving recogni- 
tion honor. Many readers and critics have highlighted the esthetic merits of the novels. My point is rather that the break with the traditional honor culture has not ruined his honor. Quite the opposite, and this fact illustrates the decline of a traditional honor culture.

Like other autobiographical texts, My Struggle performs what autobiographical texts usually do, which is constituting a self through writing. Autobiographies are never neutral reports about lived life. They create what they write about, a self with whom the writer is able to identify. In Knausgaard's case, it is obvious how in this process he writes himself out of a community with traditional honor groups - and how he instead writes himself into a new community with authors' and celebrities' honor groups. As a consequence of succeeding so well with this project, that is "achieving or displaying excellence," he is integrated in the late modern media society's group of celebrities-that is the premier honor group of our time. But such an honor group is marked with the characteristics of the liquidity of late modernity. Fame changes. Superstars flash for a while and then they extinguish. Late modern communities seldom include any guarantee of duration. One has to compete for fame and attention. We are talking here of what Stewart calls "competitive honor." And one does not get attention by being loyal to existing traditions and common norms. Attention comes with the transcending of social codes, pushing the limits and breaking the rules, including the honor codes. This is probably why Knausgaard's "honest brutality" has its effect. He is surely writing for his freedom, as he states, and not for fame; writing as an artistic fact. But the social fact is maximum prestige in the honor group of the cultural field.

\section{Conclusion}

To sum up, I think one could say that Karl Ove Knausgaard's My Struggle shows the status of the concept of honor and honor culture in some late modern societies, at least in the northern part of Europe. It is possible for individuals to set themselves free from any relation to traditional honor groups like family and guild. Likewise, it is not only possible but even highly rated, to set oneself free from traditional honor codes, including ethical norms. In accordance with the general development in late modern societies, belonging to honor groups and loyalty to honor codes are subject to choice and second choices. At the same time, Knausgaard's work and its reception show that traditional feelings and conceptions of honor still exist as a kind of leftover value among people. "Brutal revelation" of traditional honor groups can lead to great frustration, anger and even illness among those involved, even if they do not see any point in bringing 
the case to court (for instance, court cases of defamation have greatly decreased even in countries that have a tradition for such cases, like Germany). ${ }^{1}$

It may come as a surprise that even the emancipated individual, who has set himself free from traditional honor groups and honor codes, seems frustrated about the decline of an honor culture. In Knausgaard's case, this clearly comes across in connection with the feminist consequences of the fall of an honor culture. Most honor cultures have been male dominated. Late modern societies, at least in the northern parts of Europe, are developing in the direction of equality and equal rights, which unsettle the traditional male role. Knausgaard shows great frustration at the feminization of his role especially as a father:

When I was in the café feeding Vanja there was also at least one other father there, usually of my age, that is, in his mid-thirties, and who had a shaved head to hide hair loss. You hardly ever saw a bald patch or a high forehead any longer, and the sight of these fathers always made me feel a little uncomfortable, I found it hard to take the feminized aspect of their actions, even though I did exactly the same and was as feminized as they were. The slight disdain I felt for men pushing strollers was, to put it mildly, a double-edged sword as for the most part I had one in front of me when I saw them. I doubted I was alone with these feelings, I thought I could occasionally discern an uneasy look on some men's faces in the play area, and the restlessness in their bodies that made them prone to snatching a couple of pull-ups on the bars while the children played around them.

My Struggle Book 2, 73-74

1 The relationship between honor and law is a complex subject. Stewart has a whole chapter about it in his book. It appears that in countries where there has been a close relationship between honor and law, the number of cases of defamation has declined considerably. At the beginning of the 1900s, there were about 50,00o lawsuits a year in Germany. In the 1960s, the number had fallen to between 8000 and 10,000 cases (Stewart 14). Stewart cites Montaigne who said that "there are two sets of laws, those of honor and those of justice, in many matters quite opposed" (79). Montaigne also wrote that "he who appeals to the laws to get satisfaction for an offence to his honor, dishonors himself" (80). Such an inconsistency between honor cultures and legal systems seems to be a pattern in the history of honor. As a consequence, in the history of Europe in many countries one was reluctant to bring cases of dueling to court, even though it was illegal, in the same way as some honor cultures today do not deal properly with cases of so called honor killings. 
He also shows great fascination and nostalgia for a traditional honor culture when he writes about his admiration for the boxing club, of which a friend of his (Geir) is a member. In this context, he blames the late modern welfare state for having ruined values like men's honor and violence.

He had boxed in a club in Stockholm for three years in order to gain a firsthand view of the milieu he described [in his book The Aesthetics of a Broken Nose]. There the values that the welfare state had otherwise subverted, such as masculinity, honor, violence, and pain, were upheld, and the interest for me lay in how different society looked when viewed from that angle, with the set of values they had retained.

My Struggle Book 2, 127

In many ways, the decline and fall of an honor culture represents great release and liberation. It has some bizarre consequences for people who cannot stand embarrassing emotions, including others' embarrassing behavior(s). But in general it is likely that the fall of an honor culture makes it easier to foresee a society based on equality and equal rights. At the same time, it seems likely that the clash between strong and impaired honor cultures represents one of the greatest challenges of the globalized world. Against this background, a new scientific focus on honor cultures and the decline and fall of honor cultures is necessary. Partly for this reason, it is interesting to study and follow Knausgaard and his reception, not least from a global perspective.

\section{Works Cited}

Barron, Jesse. "Completely Without Dignity: An Interview with Karl Ove Knausgaard." The Paris Review. Web. 26 Oct. 2016.

Bowman, James. Honor: A History. New York: Encounter Books, 2006.

Dodds, Eric Robertson. The Greeks and the Irrational. Berkeley, CA: University of California Press, 1951.

Ellis, John. The Social History of the Machine Gun. Baltimore: Johns Hopkins UP, 1986.

Ibsen, Henrik. A Doll's House. Trans. James Walter McFarlane, London: Oxford UP, 1961.

Jordan, Justin. "The best fiction of 2013." The Guardian. Web. 26 Oct. 2016.

Klassekampen. 3 Oct. 2009, 23.

Knausgaard, Karl Ove. My Struggle, Book 2. A Man in Love. Trans. Don Barlett, New York:

Farrar, Straus and Giroux, 2014.

Knausgård, Karl Ove. Min kamp 2. Oslo: Forlaget Oktober, 2014 [2009]. 
Nussbaum, Martha. Upheavals of Thought: The Intelligence of Emotions. Cambridge: Cambridge UP, 2001.

Oprisko, Robert L. Honor: A Phenomenology. London: Routledge, 2012.

Pitt-Rivers, Julian. "Honor." In International Encyclopedia of the Social Sciences, vol. 6, 1968, 503-511.

Powers, John. National Public Radio (NP R). Web. 26 Oct. 2016.

Sessions, William Lad. Honor for Us: A Philosophical Analysis, Interpretation and Defense. London: Continuum, 2010.

Stewart, Frank Henderson. Honor. Chicago: The University of Chicago Press, 1994.

Tetzlaf, Marie. “Knausgårds mesterværk vil få lige så stor betydning som Goethe (Knausgaard's masterpiece will become as influential as Goethe)." Web. 26 oct. 2016.

Wikan, Unni. For cerens skyld. Oslo: Universitetsforlaget, 2003.

Zennström, Maria. "Det private finnes som en brist i formen," conversation with Knausgaard in Bokvennen, no. 2. Oslo: Bokvennen forlag, 2013, 39-49. 